\title{
Meat and dairy supporters seek industry- friendly changes to food guide
}

\author{
Cite as: CMAJ 2018 February 20;190:E201-2. doi: 10.1503/cmaj.109-5561
}

Posted on cmajnews.com on Feb. 1, 2018.

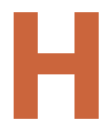
ealth Canada is facing mounting pressure to bend a revision of Canada's Food Guide to the interests of meat and dairy producers. The regulator is working on a new guide that would promote a mostly plant-based diet and warn against foods high in sodium, sugar and saturated fat, effectively discouraging consumption of many meat and dairy products.

Health experts have questioned the integrity of the current guide, which treats fruit juice as equivalent to fruit, and recommends two servings a day of meat and dairy or alternatives. This time, Health Canada has committed to greater transparency and banned meetings between lobbyists and bureaucrats working on the guide. However, there are signs industry is still exerting pressure on the process, albeit indirectly.

"My impression is that industry is circumventing the spirit of the safeguards against industry influence of the few officials who are directly responsible for revising the food guide by meeting with their colleagues or bosses all the way to the Prime Minister's Office," said Bill Jeffery, executive director of the Centre for Health Science and Law.

The federal department responsible for promoting agriculture has reportedly been lobbying officials at Health Canada to soften language in the new guide that might discourage Canadians from consuming meat and dairy. In memos marked secret and obtained through access to information requests, officials for Agriculture and Agri-food Canada warned that emphasizing plant-based sources of protein would have "negative implications for the meat and dairy industry," and urged the adoption of "more positive or neutral messaging." They also took issue with claims that plant-based diets are more sustainable, citing beef sector efforts to move toward greener practices.

More recently, parliamentarians have joined the fray. Last month, the House of Commons Standing Committee on Agricul- move that the committee extend its study of the guide to hear more from industry. He cited the agriculture committee's recommendation and argued that Health Canada should be considering "all the scientific data at their disposal," including industry-funded research. Liberal MP Bill

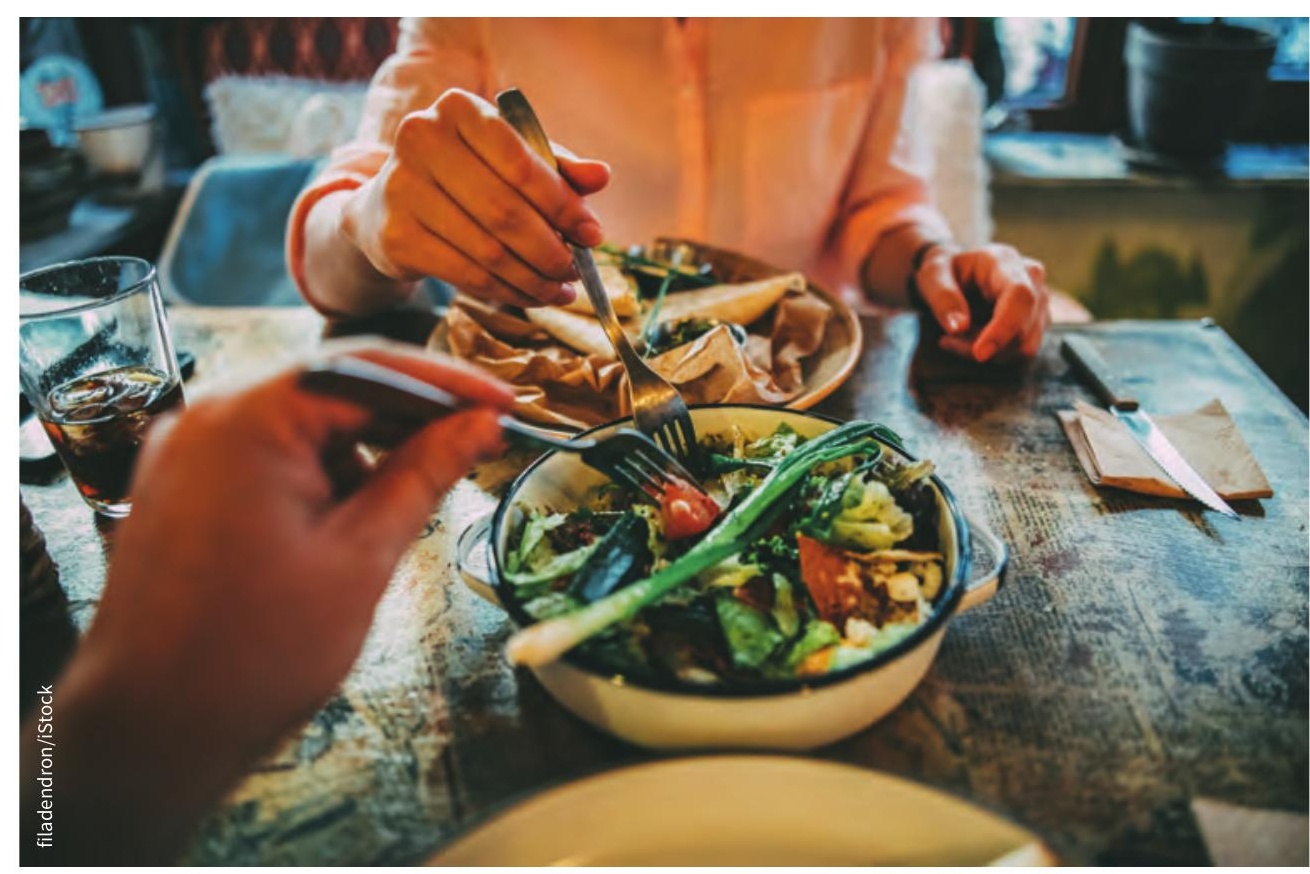

Health Canada's plans to promote a more plant-based diet have sparked political backlash from supporters of agri-food industry.

ture and Agri-Food issued a recommendation that government work with industry to "ensure alignment and competitiveness for domestic industries." The committee is working on long-term economic goals for food production and heard from industry witnesses that the revised guide would reduce consumption of their products.

Conservative MP Luc Berthold interrupted presentations from health experts to the Standing Committee on Health to
Casey objected that "another committee is telling us what this committee is supposed to study." Other members took issue with the motion being discussed publicly and moved the debate in camera.

How much this political manoeuvring will affect the final guide is unclear. In earlier testimony to the Standing Committee on Health, Dr. Hasan Hutchinson, Health Canada's lead on the guide, maintained that the revisions will be based on 
the "best available evidence." However, he noted that "we bring in the departments of the environment and agriculture as well to look at that."

According to Dr. David Jenkins, Canada Research Chair in Nutrition and Metabolism at the University of Toronto, similar pushback on American recommendations to "eat less red meat" resulted in weaker guidelines, with a final recommendation to "eat more lean meat." He and other experts fear the same will happen here, even if Health Canada continues to hold the line on the benefits of a mostly plant-based diet.

"The evidence is sufficient, but whether the evidence will prevail is a concern," said Dr. David Spence, a professor of neurology at Western University who has studied the role of nutrition in preventing stroke. "The food industry is extremely powerful, extremely well-funded and they will spend hundreds of millions of dollars to try to persuade people to their point of view," he said. "It would be very hard for anybody to resist this kind of influence."

Lauren Vogel, CMAJ 